\title{
Determination of Safe Concentration of Benzene Exposure in Workers in a Laboratory of Oil Processing Industry in Indonesia
}

\author{
Kharina Almira Djalali ${ }^{1}$, Abdul Rohim Tualeka ${ }^{1}$, Pudji Rahmawati ${ }^{2}$, Syamsiar S Russeng ${ }^{3}$, Atjo Wahyu ${ }^{3}$, \\ Ahsan $^{4}$, Dewi Kartikasari ${ }^{5}$ \\ ${ }^{1}$ Department of Occupational Health and Safety, Faculty of Public Health, Airlangga University, 60155 \\ Surabaya, East Java, Indonesia; ' ${ }^{2}$ Department of Development of Islamic Society, State Islamic University \\ Sunan Ampel, Surabaya, Indonesia; ${ }^{3}$ Department of Occupational Health and Safety, Faculty of Public Health, \\ Hassanudin University, Makassar, Indonesia; ${ }^{4}$ Faculty of Nurse, University of Brawijaya, Malang, Indonesia; \\ ${ }^{5}$ Department of Environtmental Health, Faculty of Public Health, Diponegoro University, Semarang, Indonesia
}

\begin{abstract}
Benzene is one of the substances included in the poison of air pollution. The Environmental Protection Agency (EPA) has classified benzene in Group A carcinogens for humans. The widespread use of benzene in the industrial world can have harmful consequences. The amount of exposure workers receive has a negative impact on their health. Workers at the petroleum refinery laboratory are workers at risk of exposure to benzene. The study aimed to measure the safe concentration limit in the Main Laboratory section of PT. Pertamina RU IV Cilacap. This was a cross sectional, observational, and descriptive study with 51 samples of PT Pertamina RU IV Cilacap laboratory workers. Variables of this study were benzene concentration in the workplace, working time per day, work respiration rate, worker height, weight, and body surface area, white mice body surface and weight, $\mathrm{Km}$ factor on workers (Human $\mathrm{Km}$ ), $\mathrm{Km}$ factor on animals (Animal Km), No Observed Adverse Effect Level (NOAEL), safe human dose (SHD), and benzene safe concentrations (C safe) in the air for workers.

The result indicated that safe concentration (C safe) limit in PT Pertamina RU IV Cilacap was $0.03 \mathrm{ppm}$. It is less than the safe concentration set by Minister of Manpower and Transmigration Regulation No. 13 of 2011 which stated that the $\mathrm{c}$ safe is $0.5 \mathrm{ppm}$. It showed that the TLV in the Main Laboratory section of PT. Pertamina RU IV Cilacap is not safe for workers as benzene concentration in this laboratory is 16.67 times bigger than its safe concentration of benzene.
\end{abstract}

Keywords: Benzene, safe concentration, laboratory worker

\section{Introduction}

Benzene is one of the substances included in the poison of air pollution. The Environmental Protection Agency (EPA) has classified benzene in Group A

\footnotetext{
Corresponding Author:

Abdul Rohim Tualeka

Department of Occupational Health and Safety, Public Health Faculty, Airlangga University Campus C, Jalan Mulyorejo, Surabaya, 60115, Indonesia

Phone: +62 81333519732

Email: abdul-r-t@fkm.unair.ac.id
}

carcinogens for humans. The widespread use of benzene in the industrial world can have harmful consequences. The amount of exposure workers receive has a negative impact on their health. Workers at the petroleum refinery laboratory are workers at risk of exposure to benzene. One of the chronic effects of being exposed to benzene is a bone disorder of the spinal cord which changes the blood profile.

Benzene enters the body through inhalation. It enters in the form of steam with the main absorption occurring in the lungs. A number of cases of benzene poisoning occurs through the respiratory tract in the workplace. Ninety per cent of those cases are because of inhaling the 
benzene as much as $\pm 8 \mathrm{~m}^{3}$ of air for 8 hours/day every day ${ }^{1}$ long exposure, exposure frequency, and duration of exposure. The measures include the analysis of hazard identification, dose- response analysis, exposure analysis, risk characteristics, and risk management. The results of the average concentration of benzene from 8 point was $0,287 \mathrm{mg} / \mathrm{m} 3$. The average yield intake of all workers on non-carcinogenic effects was $0.0027 \mathrm{mg} / \mathrm{kg} /$ day. The average of workers intakes of carcinogenic effect was $0.0039 \mathrm{mg} / \mathrm{kg} /$ day. A total of 19 respondents (37.35.

Benzene as a toxic substance has a safe concentration. Based on research that has been done in the PT. Pertamina RU IV Cilacap, the average concentration of benzene measured at 8 points was $0.09 \mathrm{ppm}$. It is below the Threshold Limit Value (TLV) set by Minister of Manpower and Transmigration in its regulation No. 13 of 2011 which is equal to $0.5 \mathrm{ppm}$. However, this TLV can still bring health effects for the workers. Based on the Environmental Protection Agency (EPA) research, a long-term tolerance of benzene exposure in the air with a concentration limit of $0.004 \mathrm{ppm}$ can cause case of leukemia one in 10,000 populations (2013).

Safe benzene concentration is needed as a benchmark for exposure limits that are permitted to avoid the occurrence of health effects for workers. However, many of safe concentration origin are not known. Research by Saridewi and Tualeka in 2012 shows calculation results of safe concentrations derived from NOAEL and Rfc values $^{2}$.

Based on the description above, this study aimed to determine the Threshold Limit Value of benzene in the Main Laboratory section of PT. Pertamina RU IV Cilacap.

\section{Material and Method}

It is an observational, cross sectional and descriptive study. Subject for this study is 51 out of 85 workers of the Laboratory section of PT. Pertamina RU IV Cilacap. The object sample of this study is the air in the working area of Main Laboratory and Petrochemical and Gas Laboratory of PT. Pertamina RU IV Cilacap.

Primary data is taken from the measurement of benzene concentration in the air sample in the working area of Laboratory of PT. Pertamina RU IV Cilacap and the weight of experimental animal, white mice.
Secondary data is taken from the information about working process and the number of workers involved.

The variables of this study were workplace benzene concentration, working time per day, work respiration rate, worker height, worker body weight, worker's body surface area, body surface area and weight of white mice, Human Km, Animal Km, No Observed Adverse Effect Level (NOAEL), safe human dose (SHD), and benzene safe concentrations in the air for workers (C safe).

The formula for calculating Safe Human Dose (SHD) used in this study was the formula by Shaw et al (2007)

$$
\mathrm{SHD}=\text { NOAEL } \frac{\text { Animal } \mathrm{Km}}{\text { Human } \mathrm{Km}}
$$

To determine the safe concentration of benzene for workers in the Laboratory of PT Pertamina RU IV Cilacap, the data was analyzed using manual qualitative analysis.

\section{Result}

A. Characteristic of Experimental Animal (White Mice): The toxicity of a chemical is known when the substance enters the body and affects or damages the human body. Toxicity test of a chemical can be done using experimental animals, such as white mice that qualitatively have similar response to toxins to human. Table 1 shows weight and body surface area (BSA) of white mice.

Table 1: Distribution of Experimental Animal (White Mice)

\begin{tabular}{|c|c|c|}
\hline $\begin{array}{c}\text { Experimental Animal } \\
\text { (White Mice) }\end{array}$ & $\begin{array}{c}\mathbf{W} \\
\mathbf{( k g})\end{array}$ & $\begin{array}{c}\text { BSA } \\
\mathbf{( m}^{\mathbf{2}}\end{array}$ \\
\hline 1 & 0.1405 & 0.024165 \\
\hline 2 & 0.1405 & 0.024165 \\
\hline 3 & 0.1410 & 0.024223 \\
\hline 4 & 0.1410 & 0.024223 \\
\hline 5 & 0.1395 & 0.024050 \\
\hline 6 & 0.1415 & 0.024165 \\
\hline
\end{tabular}

Based on the weight of white mice, its body surface area (BSA) can be calculated using the following formula:

Animal BSA $=0.09 \times \mathrm{W}^{0.67}$ 


\section{Annotation:}

BSA: Body Surface Area $\left(\mathrm{m}^{2}\right)$

W: Weight $(\mathrm{kg})$

B. Workers Characteristic: The characteristics of workers in this study consisted of workers' weight, height, working time and the average respiratory rate in the PT. Pertamina RU IV Cilacap. Table 2 shows the characteristics of workers.

Based on the average weight and height of the workers', body surface area and respiration rate of the workers can be calculated using the following formula:

1. The Average of Workers' Body Surface Area:

$\mathrm{BSA}=\sqrt{\mathrm{W} \cdot h / 3600}=\sqrt{67.159 / 3600}=1.72 \mathrm{~m}^{2}$

\section{Annotation:}

BSA: Body Surface Area $\left(\mathrm{m}^{2}\right)$

W: weight $(\mathrm{kg})$

$\mathrm{h}$ : height $(\mathrm{cm})$

\section{The Average of Workers' Respiration Rate}

$$
\begin{aligned}
\mathrm{BR} & =5.3 \ln \mathrm{W}-6.9 / 24=5.3 \ln 67-6.9 / 24 \\
& =0.596 \mathrm{~m}^{3} / \mathrm{jam}
\end{aligned}
$$

\section{Annotation:}

BR: Breathing Rate ( $\mathrm{m}^{3} /$ hour)

h: height $(\mathrm{cm})$

Table 2: Distribution of Workers' Characteristics, Respiration Rate and Working Time in Average

\begin{tabular}{|c|c|c|c|c|c|}
\hline $\begin{array}{c}\text { Sample } \\
\text { Size }\end{array}$ & $\begin{array}{c}\mathbf{W} \\
\mathbf{( k g )}\end{array}$ & $\begin{array}{c}\mathbf{h} \\
(\mathbf{c m})\end{array}$ & $\begin{array}{c}\text { BSA } \\
\left.\mathbf{( m}^{\mathbf{2}}\right)\end{array}$ & $\begin{array}{c}\text { BR } \\
\left(\mathbf{m}^{\mathbf{3}} / \mathbf{h}\right)\end{array}$ & $\begin{array}{c}\mathbf{t} \\
(\mathbf{h o u r} / \mathbf{d a y})\end{array}$ \\
\hline 51 & 67 & 159 & 1.72 & 0.596 & 8 \\
\hline
\end{tabular}

C. Benzene Concentration: Table 3 shows the measurement result of benzene concentration in 8 different measurement spots in the working area of laboratory of PT. Pertamina RU IV Cilacap.0

Table 3: Benzene Concentration in the Working Area of Laboratory of PT. Pertamina RU IV Cilacap

\begin{tabular}{|c|c|}
\hline Location & Concentration $\mathbf{( p p m )}$ \\
\hline Observation Table 1 & 0.011 \\
\hline Observation Table 2 & 0.006 \\
\hline Shelter D & 0.169 \\
\hline
\end{tabular}

Conted...

\begin{tabular}{|c|c|}
\hline KR Room & 0.059 \\
\hline Observation Table 3 & 0.139 \\
\hline Observation Table 4 & 0.187 \\
\hline R \& D analysis table & 0.073 \\
\hline Administration office & 0.069 \\
\hline Average & 0.09 \\
\hline
\end{tabular}

Measurement results of benzene concentration in the PT. Pertamina RU IV Cilacap shows that it is still below the TLV of $0.5 \mathrm{ppm}$, which based on the Regulation of the Minister of Manpower and Transmigration No. 13 of 2011 concerning the Threshold Limit Value of Physical Factors and Chemical Factors in the Workplace. The highest concentration of benzene in the PT. Pertamina RU IV Cilacap is $0.187 \mathrm{ppm}$, the lowest is $0.006 \mathrm{ppm}$ and the average is $0.09 \mathrm{ppm}$.

However, this is still above the minimum risk level (MRL) set by ASTDR (2007), which stated that the acute exposure ( $\leq 141$ days) is $0.009 \mathrm{ppm}$, moderate exposure (15-364 days) is $0.006 \mathrm{ppm}$ and chronic exposure ( $\geq 365$ days) is $0.003 \mathrm{ppm}$.

A. Animal Km dan Human Km: The calculation of animal $\mathrm{Km}$ and human $\mathrm{Km}$ was made as a step before determining the threshold limit value for workers.

\section{Animal Km}

Animal $\mathrm{Km}=\frac{\mathrm{W} \text { animal }}{\mathrm{BSA} \text { animal }}$

Annotation:

Animal Km: animal Km factor

W animal: animal weight (white mice)

BSA Animal: Body Surface Area of white mice Table 4 shows the result of Animal Km calculation. It shows the weight, BSA and animal $\mathrm{Km}$ of the white mice.

Table 4: Animal Km of the Experimental Animal (White Mice)

\begin{tabular}{|c|c|c|c|}
\hline $\begin{array}{c}\text { Experimental } \\
\text { Animal } \\
\text { (White Mice) }\end{array}$ & $\begin{array}{c}\text { W } \\
(\mathbf{k g})\end{array}$ & $\begin{array}{c}\text { BSA } \\
\left.\mathbf{( m}^{\mathbf{2}}\right)\end{array}$ & $\begin{array}{c}\text { Animal Km } \\
\mathbf{( W / B S A )}\end{array}$ \\
\hline 1 & 0.1405 & 0.024165 & 5.814194082 \\
\hline 2 & 0.1405 & 0.024165 & 5.814194082 \\
\hline 3 & 0.1410 & 0.024223 & 5.820914007 \\
\hline
\end{tabular}


Conted...

\begin{tabular}{|c|c|c|c|}
\hline 4 & 0.1410 & 0.024223 & 5.820914007 \\
\hline 5 & 0.1395 & 0.024050 & 5.8004158 \\
\hline 6 & 0.1415 & 0.024165 & 5.855576247 \\
\hline Rata-Rata & 0.1407 & 0.024165 & 5.82 \\
\hline
\end{tabular}

\section{Human Km}

Human $\mathrm{Km}=\frac{\mathrm{W} \text { human }}{\text { BSA human }}$

Annotation:

Human Km: human Km factor

W human: weight of workers

BSA human: Body Surface Area of workers

Table 5 shows the result of human $\mathrm{Km}$ calculation. It shows the weight, body surface area and the average human $\mathrm{Km}$.

Table 5: The average human $\mathrm{Km}$

\begin{tabular}{|c|c|c|c|}
\hline $\begin{array}{c}\text { Sample } \\
\text { Size }\end{array}$ & $\begin{array}{c}\text { W } \\
(\mathbf{k g})\end{array}$ & $\begin{array}{c}\text { BSA } \\
\left.\mathbf{( m}^{\mathbf{2}}\right)\end{array}$ & $\begin{array}{c}\text { Human Km } \\
\text { (W/BSA) }\end{array}$ \\
\hline 51 & 67 & 1.72 & 38.95 \\
\hline
\end{tabular}

E. NOAEL: No Observed Adverse Effect Level (NOAEL) is a calculation that must be done to determine the extent to which the concentration of chemicals. NOAEL of benzene is $0.022 \mathrm{mg} /$ $\mathrm{kg}$ (EPA, 2005). It is obtained by the calculation using the following formula:

$$
\begin{aligned}
\text { NOAEL Benzene }\left(\mathrm{mg} / \mathrm{m}^{3}\right) & =\frac{3 \times 0.00013 \times 8}{0.1405} \\
& =0.022 \mathrm{mg} / \mathrm{kg}
\end{aligned}
$$

F. Safe Human Dose: Safe Human Dose (SHD) can be calculated using the formula of Shaw et al (2007):

$\mathrm{SHD}=$ NOAEL $\frac{\text { Animal Km }}{\text { Human Km }}$

\section{Annotation:}

SHD: Safe Human Dose (mg/kg)

NOAEL: No Observed Adverse Effect Level (mg/kg)

Based on the formula above, SHD can be obtained by calculating NOAEL, the average animal $\mathrm{Km}$ dan the average human $\mathrm{Km}$ as follows:

$$
\mathrm{SHD}=0.022 \frac{5.82}{38.95}=0.003 \mathrm{mg} / \mathrm{kg}
$$

G. Safe Concentration of Benzene: The calculation of safe concentration of benzene in the laboratory of PT. Pertamina RU IV Cilacap can be made using William (1985) as follows:

Safe Concentration $=\frac{\mathrm{SHD} \times \mathrm{W}}{\delta \times \mathrm{BR} \times t}\left(\frac{m g}{m 3}\right)$

Conversion formula from $\mathrm{mg} / \mathrm{m}^{3}$ to $\mathrm{ppm}$ is as follows:

Safe Concentration $=\frac{m g / m^{3}}{\mathrm{MW}} \times 24.5 \mathrm{ppm}$

Annotation:

Safe concentration: safe concentration of a toxic in the air for workers $\left(\mathrm{mg} / \mathrm{m}^{3}\right)$

SHD: Safe Human Dose (mg/kg)

W: weight $(\mathrm{kg})$

$\delta: \%$ of substances absorbed by the lungs

BR: breathing rate $\left(\mathrm{m}^{3} /\right.$ hour $)$

t: working time (hour)

Based on the above formula, the results of the calculation of the safe limit of benzene concentration in the Laboratory section of PT. Pertamina RU IV Cilacap as follows:

$$
\begin{aligned}
\text { C safe }\left(\mathrm{mg} / \mathrm{m}^{3}\right) & =\frac{(0.003)(67)}{(50 \%)(0.596)(8)} \mathrm{mg} / \mathrm{m}^{3} \\
& =0.092 \mathrm{mg} / \mathrm{m}^{3} \\
\text { C safe }(\mathrm{ppm})= & \frac{\left(0.0092 \mathrm{mg} / \mathrm{m}^{3}\right)(24.5 \mathrm{ppm})}{(78.11 \mathrm{mg} / \mathrm{mol})} \\
= & 0.03 \mathrm{ppm}
\end{aligned}
$$

The calculation result of the safe concentration benzene in the air in the working area of the PT. Pertamina RU IV Cilacap can be used as a predictor of safe toxin concentration limits for workers in the workplace when the Threshold Limit Value (TLV) has not been established. It can also be used as a comparison with the current TLV set by other institutions.

\section{Discussion}

Trial activities in the Laboratory of PT Pertamina RU IV Cilacap which involves test samples in the form of crude oil and fuel-based products and non-fuel products containing benzene and which can evaporate 
at certain temperatures and pressures is a source of benzene hazards for workers. Stages of handling the test sample require combustion or heating the test sample. It causes benzene to evaporate into the air in the working environment which later can cause negative effect for workers' health. It is due to that benzene is in Group A of carcinogens for humans (EPA).

Workers in the Laboratory of PT Pertamina RU IV Cilacap work with a duration of 8 hours/day for 265 days/year. The results of interviews with 51 respondents found that $21.6 \%$ respondents reported to experience dizziness, $21.6 \%$ irritability, $17.6 \%$ sleep disorders, $13.7 \%$ breathlessness, and $11.8 \%$ nausea ${ }^{1}$ long exposure, exposure frequency, and duration of exposure. The measures include the analysis of hazard identification, dose- response analysis, exposure analysis, risk characteristics, and risk management. The results of the average concentration of benzene from 8 point was $0,287 \mathrm{mg} / \mathrm{m} 3$. The average yield intake of all workers on non-carcinogenic effects was $0.0027 \mathrm{mg} / \mathrm{kg}$ /day. The average of workers intakes of carcinogenic effect was $0.0039 \mathrm{mg} / \mathrm{kg} / \mathrm{day}$. A total of 19 respondents $(37.35$.

Calculation of safe concentration limit in PT. Pertamina RU IV Cilacap was carried out in some steps. It was started with the calculation of NOAEL, followed by calculation of SHD/Rfc and, as a final step, calculation of the safe limit of benzene concentration. Saridewi and Tualeka (2012) who conducted a study to determine the benzene safe concentration limits also performed such calculation steps using NOAEL and SHD/Rfc.

According to EPA, NOAEL (No Observe Adverse Effect Level) is an experiment in determining doses that do not indicate a statistically significant effect on toxic effects or biological functions ${ }^{3}$. NOAEL benzene values in this study is $0.022 \mathrm{mg} / \mathrm{kg}$ determined by EPA (2005). Based on research results by Swean et al (2010), the result of NOAEL benzene was $3.0 \mathrm{mg} / \mathrm{m}^{3}$ or equal to $0.022 \mathrm{mg} / \mathrm{kg}$. The research conducted by Kruskal Wallis to determine NOAEL values by testing the expression of imuneractive interleukin-2 showed that the IRS score results were not significantly different so that they could be used as a reference for NOAEL values ${ }^{3}$.

SHD (Safe Human Dose) or Rfc is a dose reference for humans. When the dose received by human exceeds the SHD/Rfc value, the risk for human health is also greater ${ }^{4}$. Generally, in the previous study, the value of
Rfc used was a provision determined by IRIS (Integrated Risk Information System) from US-EPA which was equal to $0.0086 \mathrm{mg} / \mathrm{kg} / \mathrm{day}$. However, this study obtained Rfc result of $0.003 \mathrm{mg} / \mathrm{kg}$. It was derived from the calculation of NOAEL, Animal Km and Human Km. Saridewi and Tualeka (2012) used the Rfc calculation formula and get the Rfc value of $0.004 \mathrm{mg} / \mathrm{kg}$. A research conducted at the Wedoro shoe factory, Sidoarjo, which used the same Rfc calculation formula, obtained the Rfc value of $0.0036 \mathrm{mg} / \mathrm{kg}$.

The measurement result of benzene concentration in 8 different measurement spots in the working area of laboratory of PT. Pertamina RU IV Cilacap showed that its highest benzene concentration was $0.187 \mathrm{ppm}$ and the lowest was $0.006 \mathrm{ppm}$. It is still far below the TLV set by Minister of Manpower and Transmigration in its regulation No. 13 of 2011, which stated that the TLV of benzene is $0.5 \mathrm{ppm}$.

The obtained safe concentration limit of benzene in the Laboratory of PT. Pertamina RU IV Cilacap is 0.03 ppm. It is below the TLV set by Minister of Manpower and Transmigration in its regulation No. 13 of 2011, which stated that the TLV of benzene is $0.5 \mathrm{ppm}$. It indicated that working area in the Laboratory of PT Pertamina RU IV Cilacap is not safe for workers as it is 16.67 times bigger than the safe limit in the Laboratory.

Benzene contains gasoline which can have an impact on blood hemoglobin levels. Exposure to benzene through the respiratory tract with certain doses can damage human blood cells. Benzene can provide an impact on the spinal cord which can cause aplastic anemia, immune cell damage and acute bleeding. It is proved by workers complaints of uncomfortableness of respiratory tract and eyes. The use of personal protective equipment (PPE) for workers such as masks is strongly recommended. It is to reduce their risk of inhaling benzene. It is also strongly recommended for workers to consume nutritious foods such as beef liver and salmon, to increase their immunity against benzene ${ }^{5}$.

\section{Conclusion}

1. NOAEL benzene in the Laboratory Section of PT. Pertamina RU IV Cilacap is $0.022 \mathrm{mg} / \mathrm{kg}$.

2. SHD/Rfc benzene in the Laboratory Section of PT. Pertamina RU IV Cilacap is $0.003 \mathrm{mg} / \mathrm{kg}$ 
3. Safe concentration of benzene in the Laboratory Section of PT. Pertamina RU IV Cilacap is 0.092 $\mathrm{mg} / \mathrm{m}^{3}$ or equal to $0.03 \mathrm{ppm}$.

\section{Recommendation}

The Threshold Limit Value (TLV) of benzene concentration obtained from manual calculations of this study can be used as the TLV of benzene in PT. Pertamina RU IV Cilacap.

It is strongly recommended for workers to use personal protective equipment (PPE) such as masks during working hours, and for the company to provide high nutritious food for workers.

Conflict of Interest: All authors have no conflicts of interest to declare.

Source of Funding: This is an articel "Penentuan Konsentrasi Aman Pajanan Benzene pada Pekerja di Bagian Laboraturium Industri Pengolahan Minyak Bumi“" of Occupational Health and Safety Departmen that was supported by Faculty of Public Health, Airlangga University.

Ethical Clearence: The study was approved by the institutional Ethical Board of the Public Health, Diponegoro University

\section{REFERENCE}

1. Dewi Kartikasari, Nurjazuli MR. Analisis Risiko Kesehatan Pajanan Benzene Pada Pekerja Di Bagian Laboratorium Industri Pengolahan Minyak Bumi. J Kesehat Masy [Internet]. 2016;4(4):8929. Available from: http://ejournal-s1.undip.ac.id/ index.php/jkm\%0AANALISIS
2. Saridewi N, Tualeka AR. Penentuan Konsentrasi Aman Benzena di Stasiun Pengisian Bahan Bakar Umum (SPBU) di Pancoranmas Depok. 2006;

3. Tualeka AR, Wibrata DA, Ahsan A, Rahmawati P, S Russeng S, Wahyu A, et al. Determination of Highest Dose of Ammonia without Effect at Work Environment through the Expression of Interleukin-2 Cell in Rattus Novergicus. Open Access Maced J Med Sci [Internet]. 2019 Mar 15;7. Available from: https://www.id-press.eu/ mjms/article/view/oamjms.2019.207

4. Rahman. Public Health Assessment : Model Kajian Prediktif Dampak Lingkungan dan Aplikasinya Untuk Manajemen Risiko Kesehatan. Depok; 2007.

5. Tualeka AR. Toxicology Industry \& Risk Assessment. Surabaya: Graha Ilmu Mulia; 2014.

6. Menteri Tenaga Kerja dan Transmigrasi Republik Indonesia. Peraturan Menteri Tenaga Kerja dan Transmigrasi Nomor PER. 13/MEN/X/2011 tahun 2011 tentang Nilai Ambang Batas Faktor Fisika dan Faktor Kimia di Tempat Kerja. Jakarta: Kementrian Tenaga Kerja dan Transmigrasi Republik Indonesia; 2011

7. US-EPA. Benzene (CASRN 71-43-2). Wshington, DC: Irish, US EPA; 2015

8. US-EPA. Carcinogenic effects of benzene: An update. Prepared by the national center for envirnmental health, office of search and development. Washington, DC: US EPA; 1998 